KEMAS 13 (2) (2017) 178-184
Jurnal Kesehatan Masyarakat

\title{
SALIVARY GLUCOSE LEVEL INCREASES SEVERITY OF PERIODONTAL CONDITION IN PATIENTS WITH TYPE 2 DM
}

\author{
Diyah Fatmasari $^{1 \bowtie}$, Yoga Rizki Ramadhani² ${ }^{2}$ Endah Aryati Ekoningtyas ${ }^{2}$, Tri Wiyatini ${ }^{2}$ \\ ${ }^{1}$ Dept of Dental Nurse, Health Polytechnic, Semarang, 50196, Indonesia \\ ${ }^{2}$ Faculty of Dentistry, Sultan Agung University, Semarang, 50196, Indonesia
}

\section{Article Info}

Article History:

Submitted April 2017

Accepted November 2017

Published November 2017

Keywords:

Saliva glucose level;

periodontal condi-

tion; Diabetes Mellitus.

DOI

http://dx.doi.org/10.15294/

kemas.v13i2.9471

\begin{abstract}
Saliva can be used for early detection of Diabetes Mellitus (DM). The purpose of the study was to determine the relationship between salivary glucose level of patients with type $2 \mathrm{DM}$ on periodontal tissue and to compare it with non DM condition. Observational analysis with cross sectional study was the design used with 40 patients in each group as samples. Periodontal conditions were examined using a dental probe and salivary glucose levels with Eppendorf Ecom 6125 Photometer. The data was analysed statistically with Spearman test to find the relationship between salivary glucose level and periodontal condition and Mann Whitney U Test to compare DM and non DM groups. Cofficient value of Spearman was 0.86 , there was a strong correlatiom between salivary glucose level and periodontal condition. Salivary glucose level of DM patients was 8.55 and the control group's was $1.85(\mathrm{p}=0.02)$. Higher salivary glucose level would increase severity of periodontal tissue status
\end{abstract}

\section{Introduction}

Saliva is a fluid consisting of secretion from saliva glands and gingival crevicular fluid. About $90 \%$ is produced by major salivary glands (parotid, sub mandible and sublingual glands) and around $10 \%$ by minor glands (oral mucosa in lingual, labial, buccal, palatinal and glossopalatinal). In healthy condition, oral mucosa can produce about $500 \mathrm{ml}$ to $1.5 \mathrm{~L}$ saliva (Brosky, 2007). Saliva function ranges from the digestion process by wetting the food particles which allows for easy mastication, has antibacterial property, helps with speaking by making the movement of lips and tongue easier (Saputri, 2010). Saliva contains several proteins (amylase, mucin, histatin, cystatin, peroxidase, lysozyme, and lactoferin), electrolytes $\left(\mathrm{Na}^{+}\right.$,
$\mathrm{K}^{+}, \mathrm{Cl}^{-}, \mathrm{HCO}^{3-}, \mathrm{Ca}^{2+}, \mathrm{Mg}^{2+}, \mathrm{HPO}_{4}^{2}, \mathrm{SCN}^{-}$, and $\mathrm{F})$, immunoglobulin (IgA, IgG, and $\operatorname{IgM}$ ), and organic molecules (glucose, amino acid, urea, uric acid and fat). One of the organic molecules found in saliva is glucose which has a role as a fuel for the human body cells and as a carbon source for compound synthesis (Djakani, 2013).

Proteins, electrolytes, and organic molecules in saliva could potentially act as an alternative bio fluid for early detection of systemic diseases. Systemic disease is a pathological condition which spreads and attaches to the whole body system. Some diseasees classified as systemic disease are cardiovascular, kidney disease and diabetes mellitus (DM) (Malamud, 2011). Diabetes mellitus is a chronic disease which is

\footnotetext{
$\square$ Correspondence Address:

Dept of Dental Nurse, Health Polytechnic, Semarang, 50196, Indonesia

Email : fatmasaridiyah@gmail.com
} 
characterized by impaired insulin production, carbohydrate metabolism, fat, protein, blood vessel structure and function disorder (Rattu, 2012). There are several types of Diabetes, type 1 Diabetes, type 2 Diabetes, and Gestational Diabetes. Type 2 diabetes is the most common found in patients (Ship, 2003). About 90-95\% of cases are type 2 Diabetes while cases of type 1 are around 5-10\% (Sukminingrum, 2012). Type 2 Diabetes or Non-Insulin Dependent Diabetes Mellitus (NIDDM) occurs as a result of the decrease in peripheral tissue response to insulin or the so-called insulin resistance and decrease of ability of pancreatic $\beta$ cells to produce insulin (Dipti, 2016).

Type 1 diabetes mellitus is caused by viral infection, administration of toxin, diabetogenic (streptozotosin, alloxan) or genetically mediating degeneration of pancreatic $\beta$-Langerhans cells resulting in a very low or a complete halt in the production of insulin. The etiology of type 2 diabetes mellitus is caused by two factors: (1) decreased peripheral tissue response to insulin or insulin resistance, and (2) decreased ability of pancreatic $\beta$ cells to secrete insulin in response to glucose load (Nugroho, 2006).

Patients with diabetes mellitus often do not realize their disease until specific symptoms such as periodontal disease (gingivitis and periodontitis), dental caries and tooth loss, impaired salivary function, poor healing of mouth sores appeared (Al-Maskari, 2011). The most important thing that occurs in patients with diabetes mellitus is an increase in the prevalence of periodontal disease, which is a bacterial infection of the periodontium which results in the loss of attachment of teeth and bones, bleeding during probing, and increased gingival inflammation (Rattu, 2012).

Periodontal disease is an inflammation which occur in dental support tissues including gingivae, periodontal ligaments, alveolar bone, and cementum. Periodontal disease includes gingivitis and periodontitis. Gingivitis is an inflammatory condition of the papilla and the reversible gingival edges. Periodontitis is an inflammation of the dental supporting tissues caused by microorganisms, resulting in progressive damage of the periodontal ligament and by the formation of pockets, recessions or both (Saptorini, 2011). The first stage of periodontal disease is gingivitis which, if not treated, could develop into periodontitis (Wahyukundari, 2009).

Glucose level in the blood in diabetic patients has been proven, however the relationship between glucose levels in saliva in diabetic patients and their periodontal condition need to be further investigated.

\section{Methods}

We used observational analysis design with a cross sectional approach. The dependent variable was salivary glucose level. Saliva glucose level used was the saliva glucose level from uncontrolled type 2 diabetes mellitus and salivary glucose in healthy subjects. Those with uncontrolled diabetes mellitus had a salivary glucose level of $8.09 \pm 6.45 \mathrm{mg} / \mathrm{dL}$, whereas in healthy individuals the salivary glucose level was $1.89 \pm 1.44 \mathrm{mg} / \mathrm{dL}$ (Panchbhai, 2010). Glucose is a small molecule capable of moving easily through the blood vessel membrane, from the blood plasma to the gingival fluid through the gingival sulcus, finally reaching the saliva (Vasconcelos, 2010). The saliva of type 2 diabetes mellitus and healthy people who do not have diabetes mellitus were collected by opening the mouth slightly, allowing the saliva to flow in the provided container without stimulation and the salivary glucose level was measured using a device called Eppendorf Ecom 6125 Photometer. The scale of measurement data of saliva glucose level is a ratio.

The independent variable was periodontal abnormalities. The periodontal abnormalities will be measured by an index called the Community Periodontal Index of Treatment Needs (CPITN) through periodontal periodic examination using a periodontal probe. The examination is done by probing on each tooth index by moving the WHO probe around the tooth (Lumentut, 2013).

Measurements were divided into 6 sectan, each tooth on each side was measured for the depth of the sulcus, and then the highest score was recorded. Teeth examined were 17, $16,11,26,27,47,46,31,36$, and 37 (Chriestedy, 2010).

The population was all patients with type 2 uncontrolled Diabetes at Endocrine Disorder Clinic Sultan Agung Islamic Hospital 
in Semarang, Indonesia. The samples were 40 patients with random size selection from all patients who visited the clinic and 40 patients without $\mathrm{DM}$ as a control group. Inclusion criteria were patients aged 40-60 years old, not pregnant, not taking medication which affect salivary flow, not edentulous, non-alcohol consumers, nonsmokers, not suffering from Sjorgen syndrome and not in radiation therapy.

Ethical clearance had been granted from the Health Research Ethic Committee Faculty of Dentistry Sultan Agung University. Informed consent was given to patients before data collection. The next step was to check the blood sugar level and to collect saliva from patients both on DM group and control group. Saliva collection was done in the morning before breakfast and 90 minutes after that blood glucose level was collected (Vasconcelos, 2010). Eppendorf Ecom 6125 Photometer was used to measure the saliva glucose level and the reagents were Phosphate Buffer $200 \mathrm{mmol} / \mathrm{L}$, Phenol $4 \mathrm{mmol} / \mathrm{L}, 4$-aminoantiphyrine 0,2 $\mathrm{mmol} / \mathrm{L}$, Glucose Oxidase $>15 \mathrm{KU} / \mathrm{L}$ and Peroxidase $>1,2 \mathrm{KU} / \mathrm{L}$.

Community Periodontal Index of Treatment Needs (CPITN) was used as an indicator for periodontal status of patients, with dental probe as the instrument (Genco, 2012). Research site was at Endocrine Disorder Clinic Islamic Sultan Agung Semarang Hospital and Clinical Laboratory IBL Semarang. Measurement scale of glucose level at saliva and periodontal status was in ratio. Shapiro-Wilk and Levene test were used to measure normality and homogeneity data. It was found that the data was not normal and inhomogeneous, therefore Non Parametric Statistic was employed, MannWhitney and Spearman test were done to find the relationship between salivary glucose level and periodontal status.

\section{Result and Discussion}

Most of the respondents were female and based on age of respondent half of them were 54-60 years old.

The average of glucose salivary level on patients with type-2 DM was higher than on patients with no DM, and significance measured with Mann-Whitney was 0.02 .

\begin{tabular}{clcc}
\multicolumn{4}{c}{ Table 1. Description Characteristic Respondents } \\
\hline No & Characteristic & $\mathrm{n}$ & $(\%)$ \\
\hline 1 & Gender & & \\
& Man & 10 & 25 \\
& Female & 30 & 75 \\
2 & Age & & \\
& $40-46$ & 4 & 10 \\
& $47-53$ & 16 & 40 \\
& $54-60$ & 20 & 50 \\
\hline
\end{tabular}

Source : Primary Data

Table 2. Glucose Salivary Level (mg/dL)

\begin{tabular}{lcccc}
\hline \multicolumn{1}{c}{ Group } & Min & Max & Mean & SD \\
\hline $\begin{array}{l}\text { Patients } \\
\text { type } 2\end{array}$ & 6 & 14 & 8.55 & 2.63 \\
DM & & & & \\
Non DM & 1 & 3 & 1.85 & 0.81 \\
\hline \multicolumn{5}{l}{ Source : Primary Data }
\end{tabular}

Table 3. Status of Periodontal Index

\begin{tabular}{lllll}
\hline \multicolumn{1}{c}{ Status } & \multicolumn{2}{c}{ Type 2 DM } & \multicolumn{2}{c}{ Non DM } \\
& $\mathrm{n}$ & \multicolumn{1}{c}{$\%$} & \multicolumn{1}{c}{$\mathrm{n}$} & $\%$ \\
\hline Healthy & 0 & 0 & 20 & 50 \\
Bleeding & 0 & 0 & 4 & 10 \\
Calculus present & 16 & 40 & 16 & 40 \\
$\begin{array}{l}\text { Periodontal pocket } \\
\geq 4-5 \mathrm{~mm}\end{array}$ & 24 & 60 & 0 & 0 \\
$\begin{array}{l}\text { Periodontal pocket } \\
\geq 6 \mathrm{~mm}\end{array}$ & 0 & 0 & 0 & 0 \\
\hline
\end{tabular}

Source : Primary Data

It could be seen that most patients with uncontrolled type $2 \mathrm{DM}(60 \%)$ suffer from periodontal pocket $\geq 4-5 \mathrm{~mm}$. Result of Spearman test was Coefficient Correlation score of 0.86 . It was shown that there was a very strong relationship between salivary glucose level and periodontal status-the higher the salivary glucose level, the worse the periodontal status of patients.

Periodontal disease is a multifactorial disease caused by an imbalance between environmental factors such as periodontal pathogens and body defenses, although other factors may affect periodontal tissue, but systemic factors alone in the absence of 
bacterial plaque cannot trigger periodontitis (Hamrun, 2011). There are two main factors causing periodontal disease, the primary and secondary factors. The primary factor is bacterial irritation. Bacteria are present in the saliva, on the cheeks and tongue, on the tooth surface, especially in the fissure and neck region of the gingiva. The number of bacteria in the saliva reaches hundreds of millions per millimeter, but the largest bacterial population can be found on the dorsum of the tongue. Bacteria are also found in plaques that vary depending on the individual, the position in the oral cavity, and the age of the plaque itself. The 1-2 day plaque is mostly composed of Gram-positive bacteria and Gram-negative bacteria in the form of coccus and stems. This organism grows on the enamel attached to enamel, cementum, or dentine. Plaque that grows 2 to 4 days undergo changes in the number and types of microorganisms, Gramnegative coccus bacteria and Gram-negative stem bacteria increases, the bacteria bacili fusiformis and filaments also clearly increases. The $4^{\text {th }}$ day until the $9^{\text {th }}$, the microorganisms become increasingly complex with increasing motility bacteria, such as spirochete and spirilla (Fedi, 2004).

Plaque formation itself begins with the presence of saliva in the form of a thin deposit of salivary proteins composed of glycoproteins on tooth surfaces, on restorations, and on artificial teeth. The particles are transparent, smooth, colorless, and thin, with only about $0.5 \mu \mathrm{m}$ thickness. Minutes after the deposition of the pellicle, the pellicle will be populated with bacteria. The bacteria can be directly deposited on the enamel by first attaching to the pelvis, the soft, non-calcified, bacterial layer accumulating and attaching to the teeth, the artificial teeth, the restoration, and the calculus called plaque. Plaque in the form of a thin layer is generally invisible and can be seen with disclosing material, while plaque in the form of a thick layer can be seen as grayish or yellowish deposits which cannot be removed by rinsing alone, but can be removed by brushing. Plaque consists of microbial and extracellular product residues from plaque bacteria. Proteins, fats, and carbohydrates are also present in the plaque. The inorganic components are calcium, magnesium, phosphorus, sodium, and potassium. Calcium ions in the inorganic components of plaque help to attach between bacteria and bacteria with the pellicle.

Most of the respondents were female. It can be concluded that most patients with type $2 \mathrm{DM}$ who visited Endocrine Disorder Clinic Islamic Sultan Agung Hospital Semarang were female. It was supported by a research which found that women have more risk of suffering from type $2 \mathrm{DM}$ as physically they have a greater chance of increased body mass due to the monthly menstrual cycle and post-menopausal effects causing body fat accumulation as a result of the hormonal processes (Ship, 2003).

Based on the characteristics of the respondents, the results of this study when viewed in terms of age, the highest number of respondents were in the 54-60 years age group, which is consistent with the results of a research conducted by Trisnawati (2013). This states that the risk of diabetes increases with age, especially at age $>40$ years, because at that age an increase in glucose intolerance starts to appear. The aging processes also reduce the ability of pancreatic $\beta$ cells in producing insulin. In addition, such age is also associated with increased risk of high blood glucose level. The increasing age also decreases the ability of tissues to take up glucose from blood (Amir, 2015).

None of the patients with type $2 \mathrm{DM}$ had healthy periodontal condition. Most of them had $\geq 4-5 \mathrm{~mm}$ periodontal pockets. Alternatively, the periodontal status of non DM patients are mostly in healthy condition. Only a few had periodontal pockets $\geq 4-5 \mathrm{~mm}$ and periodontal pockets $\geq 6 \mathrm{~mm}$. Patients with DM had periodontal disorder, which was caused by periodontium bacteria, the loss of attachment of teeth and bone, bleeding during probing, and increased gingival inflammation. Chronic hyperglycemia would also increase collagenase activity and its effect would break down collagen and decrease the synthesis of collagen, resulting in damaged periodontal ligament, periodontal attachment loss and alveolar bone and teeth (Emor, 2015).

Based on the results of salivary glucose level examination in uncontrolled type 2 diabetes mellitus in this study, we found the 
highest to be at $14 \mathrm{mg} / \mathrm{dL}$ and the lowest at 6 $\mathrm{mg} / \mathrm{dL}$ with an average of $8.55 \mathrm{mg} / \mathrm{dl}$. Results of salivary glucose examination in nondiabetes mellitus subjects showed the highest level was at $3 \mathrm{mg} / \mathrm{dL}$, and the lowest at $1 \mathrm{mg} /$ $\mathrm{dL}$ with an average of $1.85 \mathrm{mg} / \mathrm{dL}$. These results indicate that saliva glucose level in patients with uncontrolled type 2 diabetes mellitus was higher than in non-diabetes mellitus patients. This is also in accordance with the results of previous research conducted by Vasconcelos (2010) which states that glucose is a small molecule capable of moving easily across the vascular membrane, from the blood plasma to the gingival fluid through the gingival sulcus and reaching the saliva. Increased blood glucose levels in diabetics can lead to high levels of salivary glucose as a result of loss of homeostatic ability.

There was a very strong relationship between salivary glucose level and periodontal condition. High levels of glucose in saliva supported the proliferation of microorganisms and would increase its colonization on the teeth and oral mucous membranes and will affect periodontal disorder (Panchbhai, 2010). Glucose provides nutrition for microorganism, Candida, and suppress the killing power of neutrophils and is most likely shown in the high salivary glucose levels in diabetics. Oral diseases as a manifestation of the increased of salivary glucose level include candidiasis, dental caries, gingivitis, periodontal disorder, burning mouth sensation, fungi and bad wound healing. Patients with diabetes mellitus with increased salivary glucose levels and gingival fluid also undergo changes in the environment of microflora and bacteria can induce changes qualitatively. Such changes lead to a more severe periodontal disease (Matthews, 2002).

Diabetes mellitus is one of the systemic factors that is included in the secondary factors that cause the occurrence of periodontal disease. It is known that diabetes mellitus is a predisposing factor which exacerbates the occurrence of periodontal disease. In people with diabetes mellitus there is an increase in blood sugar levels, which suppresses the host's immune response and can lead to poor wound healing and recurrent infections. In the above description it has been explained that the main cause of periodontal disease is bacteria found in the plaque, the action of the bacteria can cause periodontal disease through several stages.

The first stage is bacterial invasion, which occurs if there are enough pathogenic bacteria on the tooth surface around the gingiva for long periods of time, thus making the tissue exposed to the bacteria-generated toxin products. In the second stage, cytotoxic agents, such as endotoxin which is the substance of polysaccharides in Gram-negative bacteria's cell wall, cause tissue necrosis. The third stage is caused by an enzyme, such as a collagenase enzyme that can decompose fibrils and collagen fibers, a hyaluronidase enzyme that can hydrolyze hyaluronic acid, a polysaccharide to attach tissues. This enzyme is produced by the host and microorganisms. The chondroitinase enzyme, which can chondroleze chondroitin sulphate which also serves to attach tissue, and then there is a protease enzyme that increases capillary permeability and destroys the non-collagen protein. The fourth stage is the immunologic response arising from inflammation induced by the plaque antigen, the immunologic response potentially causing tissue damage (Fedi, 2004).

Diabetes mellitus is a metabolic disorder characterized by hyperglycemia that occurs due to the disruption of activity or secretion of insulin (Matthews, 2002). This hyperglycemic condition will cause tissue damage along with the beginning of blood vessel damage (endothelial dysfunction). This condition causes mitochondria to produce excessive superoxide $\left(\mathrm{O}_{2}\right)$ due to increased metabolism and increased oxidative stress, which will cause DNA damage and the activation of enzyme Polyadenyl Phosphate Ribose Polymerase (PARP) that will inhibit Glyceraldehyde Phosphate Dehydrogenase (GAPDH), which is an enzyme that plays a role in glycolysis and causes disturbed glycolysis (Yerizel, 2012). This condition will result in the emergence of a joint reaction, the polyol pathway which occurs in blocked glycolysis, which will result in oxidative stress in the cell. This happes because the process of glucose being reduced into sorbitol uses NADPH, an important element in the formation of gluthathione antioxidants in cell.

Severe condition of peridontal ligament 
on patients with type $2 \mathrm{DM}$ need special treatment and attention. Some patients have psychological stress because they have to do multiple treatment to care for the disease such as adjusting their diet, frequently injecting insulin, doing exercise regularly, and taking medicines. A research on an attempt to try to reduce stress on DM patients type 2 by progressive muscle relaxation reached a conclusion that such relaxation can reduce psychological stress (Maghfira, 2015). However the contrary result found that muscle relaxation has no significant retationship with self-care behaviour.

Patients with DM need a specific self-care for maintaining their oral hygiene. An effort to improve the self-care skill should be done. Dental health education (DHE) done personally or in group can be implemented either in hospitals/clinics or in the neihgbourhood. The best method for giving DHE by dental professionals should be searched. A research found that discussion in small group was more effective to improve dental hygiene than classical lecture (Santoso, 2017). Patients can explore their experience and curoisity about dental hygiene by discussion. They can also express their motivation in the such method.

Patients with DM tend to have higher motivation to care for their periodontal condition compared to patients with no DM, which is similar with the differences of motivation between children, teenager and adult to take care of their teeth (Fatmasari and Saadah, 2014).

\section{Conclusion}

There was a very strong relationship between salivary glucose level and periodontal disease. The higher the glucose level in the saliva the worse the periodontal condition.

\section{References}

Al-Maskari, A.W., Al-Maskari, M.Y., Al-Sudairy, S. 2011. Oral Manifestations of Diabetes Mellitus, SQU Medical Journal, 11(2) : 179186.

Amir, S.M.J., Wungouw, H., Pangemanan, D, 2015. Kadar Glukosa Darah Sewaktu pada Pasien diabetes Mellitus Tipe 2 di Puskesmas Bahu Kota Manado, Jurnal e-Biomedik (eBm), 3(1) : 32-40.

Brosky, M.E, 2007.The Role of Saliva in Oral Health: Strategies for Prevention and Management of Xerostomia. The Journal Of Supportive Oncology, 5(5) : 215-225.

Chriestedy, R., Sari, D.S., Arina, Y.M.D. 2010. Tingkat Kebutuhan Perawatan Periodontal Berdasarkan Kunjungan Pasien di RSGM FKG Universitas Jember Bulan Agustus 2009-Agustus 2010. National Scientific Seminar in Periodontics 1 (NASSIP). Surabaya, Indonesia.

Dipti KH, Maitreyee DS, Shivasankara AR, Avinash SS, Malathi M, 2016. A Correlative Study of Salivar and Plasma Glucose Level in Type 2 Diabetic Patients with and without Complication, International Journal of Clinical Biochemistry and Research, 3(2) : 250-54.

Djakani, H., Masinem, T.V., Mewo, Y.M, 2013. Gambaran Kadar Gula Darah Puasa pada Laki-Laki Usia 40-59 Tahun. Jurnal e-Biomedik (eBM), 1(1) : 71-75.

Emor, S.F., Pandelaki, K., Supit, A.S.R, 2015. Hubungan Status Periodontal dan Derajat Regulasi Gula Darah Pasien Diabetes Mellitus di Rumah Sakit Umum Pusat PROF. DR. R. D. Kandou Manado.Jurnal e-GiGi (eG), 3(1) : 210-215.

Fatmasari D, Saadah L, 2014, Motivation Differences of Children, Teenager and Adult Patients Orthodontic Dental Care, Kemas Journal, 10 (1) : 21-24.

Fedi, P.F. Vernino, A.R. Gray, J.L. 2004. Silabus Periodonti. Jakarta: EGC.

Genco RJ, 2012. Salivary Diagnostic Test. J Am Dent Assoc 143 (10 Suppl): 675-87.

Hamrun, N., Hatta, M. 2011. Polimorfisme Gen Vitamin D Receptor pada Penderita Periodontitis Kronis. JST Kesehatan. 1(2). 165-172.

Lumentut, R.A.N., Gunawan, P.N., Mintjelungan, C.N. 2013. Status Periodontal dan Kebutuhan Perawatan padaa Usia Lanjut. Jurnal e-GiGi (eG), 1(2) : 79-83.

Maghfira S, Sudiana IK, Widyawati IY. 2015. Relaksasi Otot Progresif terhadap Stres Psikologis dan Perilaku Perawatan Dini Pasien DM tipe 2, Jurnal KEMAS, 10 (2) : 137-146

Malamud, D., Rodriguez-Chavez, I.R., 2011. Saliva as a Diagnostic Fluid, Dent Clint North Am, 55(11) : 159-178.

Matthews, D.C, 2002. The Relationship Between Diabetes and Periodontal Disease, Journal de I'Association Dentaire Canadienne, 68(3) : 161-164.

Nugroho, A.E. 2006. Hewan Percobaan Diabetes Mellitus : Patologi dan Mekanisme Aksi 
Diabetogenik. Biodiversitas, 7(4) : 378-382.

Panchbhai, A.S., Degwekar, S.S., Bhowte, R.R. 2010. Estimation of Salivary Glucose, Salivary Amylase, Salivary Total Protein and Salivary Flow Rate in Diabetics in India, Journal of Oral Science, 52(3) : 359-368.

Rattu, A.J.M., Tambunan, E., Barung, N.A, 2012, Periodontal Condition of Patients Type 2 Diabetic at General Hospital Manado. Dentire, 1(2) :128-135.

Santoso B, Ekoningtyas EA, Fatmasari D. 2017. Improving Elderly's Dental Hygiene Through Nursing Home Staff's Dental Health Education at the Nursing Home. Kemas Journal, 12 (2) : 189-198.

Saptorini, K.K. 2011. Poket Periodontal pada Lanjut Usia di Posyandu Lansia Kelurahan Wonosari Kota Semarang. Prosiding Seminar Nasional, Indonesia.

Saputri, T.O., Zala. H.Q., Arnanda, B.B., Ardhani, R.. 2010.Saliva as an Early Detection Tool for Chronic Obstructive Pulmonary Disease Riskin Patients with Periodontitis, Journal of Dentistry Indonesia, 17(3) : 87-92.

Ship JA, 2003.Diabetes and Oral Health: An
Overview. J Am Dent Assoc 134. Spec No 4S-10S.

Sukminingrum, Ninin, Masudi, Sam’an. 2012. Diabetes Mellitus Management in Dental Practice. Dentika Journal, 17(1) : 93-98.

Trisnawati, S.K, Setyorogo, S. 2013. "Faktor Risiko Kejadian Diabetes Mellitus Tipe II di Puskesmas Kecamatan Cengkareng Jakarta Barat Tahun 2012". Jurnal Ilmiah Kesehatan, 5(1) : 6-11.

Vasconcelos, A.C.U., Soarez, M.S.M., Almeida, P.C., Soarez, T.C. 2010. Comparative Study of the Concentration of Salivary and Blood Glucose in Type 2 Diabetic Patients, Journal of Oral Science. 52(2). 293-298.

Wahyukundari, M.A. 2009. "Perbedaan Kadar Matrix Metalloproteinase-8 Setelah Scaling dan Pemberian Tetrasiklin pada Penderita Periodontitis Kronis". Jurnal PDGI, 58(1) : 1-6.

Yerizel, E., Manaf, A., Yanwirasti, Oenzil, F. 2012. Rerata Aktivitas Polyadenylphospate Ribose Polymerase (PARP) pada Kelompok Penyandang DM tipe 2. J Indonesia Med Assoc, 62(12) : 467-470 